\title{
Socio-environmental cooperation and conflict? A discursive understanding and its application to the case of Israel and Palestine
}

\author{
T. Ide ${ }^{1}$ and C. Fröhlich ${ }^{2}$ \\ ${ }^{1}$ Research Group Climate Change and Security, Institute of Geography, University of Hamburg, \\ Hamburg, Germany \\ ${ }^{2}$ Institute for Peace Research and Security Politics at the University of Hamburg, Hamburg, Germany \\ Correspondence to: T. Ide (tobias.ide@zmaw.de)
}

Received: 24 April 2015 - Published in Earth Syst. Dynam. Discuss.: 22 May 2015

Revised: 17 August 2015 - Accepted: 20 September 2015 - Published: 13 October 2015

\begin{abstract}
The existing literature faces difficulties when accounting for the simultaneity of socio-environmental conflict and cooperation. We suggest that this puzzle can be solved by more recent constructivist works, which argue that conflictive or cooperative behavior is driven by discursively constructed interests, identities and situation assessments. Based on a literature review and field interviews, we analyze and compare the dominant water discourses in Israel and Palestine with the discourse dominant among the activists of a water cooperation project between communities from Israel and the West Bank. Our main result is that discourses are indeed crucial for understanding water-related conflict and cooperation. This finding highlights the relevance of constructivist approaches in the study of socio-environmental conflict and cooperation as well as of practices of bottom-up discursive conflict transformation.
\end{abstract}

Climate change is likely to alter temporal and spatial patterns of water and land availability, thus causing problems of resource scarcity in some regions of the world (IPCC, 2014). Especially in regions characterized by an arid or semi-arid climate, issues of land and water availability are often deeply intertwined for at least two reasons. Firstly, the use of a given piece of land (e.g., for agriculture or settlement) is usually only possible if access to adequate water resources is secured. Secondly, water is often closely connected to land in symbolic and legal terms (de Châtel, 2007; Derman et al., 2008).

A large body of literature has recently discussed whether the scarcity of water and/or land resources facilitates violent conflict or intergroup cooperation, and if so, how and under which circumstances (Ide and Scheffran, 2014). Africa has been a focal point of this discussion and the literature has documented several notable examples of socioenvironmental conflict (e.g., Nyong, 2007; Schilling et al.,
2012) or socio-environmental cooperation (e.g., Bogale and Korf, 2007; Duffy, 2006), especially in the Sub-Saharan region. However, existing research faces problems when waterand/or land-related conflict and cooperation occur simultaneously or at least in very similar geographic, ecological and political settings (see below). This is exactly the puzzle we are seeking to address in our study.

We focus on the case of Israel and Palestine because the simultaneity of water-related conflict and cooperation is especially striking in this context while sufficient data for our research design are available. But while the Israeli-Palestinian context is quite special in several regards (Moore and Guy, 2012), we are optimistic that our findings on the relevance of discourses for socio-environmental conflict and cooperation are valid in other contexts, such as Sub-Saharan and especially Northern Africa (the climatic land use patterns of which are similar to those in the Middle East), as well. This is the case because if discursive factors can explain the occurrence of cooperation in the midst of an "intractable conflict" (Bar-Tal, 1998, p. 22), they are likely to have some explana- 
tory power in less-deadlocked conflict settings, too. Our findings are also well in line with the theoretical expectations as discussed in Sect. 2.

There clearly exists a severe water conflict between Israel and Palestine, which is driven by disputes over the distribution of water from shared groundwater aquifers and the Jordan River (Zeitoun, 2008), over water pollution originating in the West Bank and Israel (Fischhendler et al., 2011), and over permissions for the construction and maintenance of water infrastructure in the Occupied Palestinian Territories (Selby, 2013). Water is one of the topics which has proven very contentious in past Israeli-Palestinian negotiations and has always been postponed to the final status talks (Lautze et al., 2005). The water conflict between the Israelis and Palestinians is embedded into and closely connected to the dynamics of the wider Israeli-Palestinian conflict which has been going on for almost a century (Moore and Guy, 2012).

However, there is also Israeli-Palestinian cooperation on water issues, especially on the scientific and civil society level. Such cooperation is remarkable within a political context that is characterized by mutual suspicion and hostility. It is part of a counter movement that has been developing since the early 1990s (Isaac and Shuval, 1994) and focusses on the cooperative potential of fair and mutually beneficial joint water management and its possible role for peacemaking and peace-building (Coskun, 2009; Kramer, 2008). This is not to say that such water cooperation is entirely unproblematic. Indeed, it is accused of marginalizing elements of the Palestinian discourse (Alatout, 2006), of de-politicizing water-related inequalities (Aggestam and Sundell-Eklund, 2014) and of privileging an artificial local vis-à-vis a more authentic "local-local" and "everyday" (Richmond, 2009, p. 325). But we believe that this form of cooperation is much more promising in overcoming "peace gaps" (Aggestam and Strömbom, 2013, p. 109) and realizing a more equitable sharing of water rights than currently dominant forms of water conflict (Harari and Roseman, 2008).

As mentioned above, the scientific literature has problems explaining such simultaneity of socio-environmental conflict and cooperation within the same setting, particularly if water cooperation is occurring under conditions of wider political conflict. One might distinguish three broad perspectives here.

The environmental peace perspective argues that shared environmental challenges, such as the degradation of crossborder water resources, can stimulate cooperation (Ide and Scheffran, 2014, 273-277). This is the case because environmental problems affecting several groups either provide material incentives (e.g., benefits created through coordinated water management) to engage in cooperative behavior, or because they produce a "community of sufferers" (Fritz, 1996, p. 28) with a higher level of empathy and solidarity towards each other (Conca and Dabelko, 2002). However, the environmental peace perspective cannot explain why shared water problems have not facilitated the termination of the
Israeli-Palestinian water conflict and more intense water cooperation on the inter-state level.

The environmental conflict perspective claims that the scarcity of renewable resources, such as water, increases the risk for (violent) conflict between social groups (HomerDixon, 1999). This is especially so if the relations between the respective groups are characterized by pre-existing political or cultural tensions, unequal access to the resources in question and/or the socio-political marginalization of one group (Barnett and Adger, 2007; Deligiannis, 2012). This is certainly the case for water relations between Israel and Palestine. But the environmental conflict perspective cannot explain why actors from both countries still engage in waterrelated cooperation. One might argue that this cooperation largely takes place between NGOs or academic actors, which face fewer constraints (e.g., from their constituencies, international partners or potential coalition partners) than elected politicians at the international parquet (Coskun, 2009). But such constraints also provide incentives towards cooperation rather than conflict, while scholars and activists often experience considerable pressures when they engage in more cooperative relationships (Alatout, 2006). Beyond this, there is still no explanation for why some scientists, local communities and NGOs in Israel and Palestine do engage in waterrelated cooperation, while most do not.

The parallel perspective highlights that water cooperation and water conflict often take place simultaneously (Zeitoun and Mirumachi, 2008). But in many cases, water cooperation only exists on a rather superficial level and tends to obscure or even perpetuate strong inequalities in power, welfare and access to water, which form the basis of (manifest or latent) water conflicts (Cascão, 2008; Funder et al., 2012). In the case of Israel and Palestine, water cooperation indeed takes place in the face of strong water-related inequalities and so far these inequalities persist (Selby, 2013). However, many scholars and activists do actively problematize such inequitable water relations and even aim to change them, although this is far from easy (Aggestam and Strömbom, 2013). The conclusion that water cooperation often exists in parallel with, and frequently obscures, water-related conflicts also leaves unexplained why some actors engage in cooperative and others in conflictive practices when they are equally powerful and similarly affected by water problems (such as the numerous Israeli and Palestinian communities along the Green Line, some of which cooperate on water while most do not).

This article takes a constructivist stance in order to explain the simultaneity of water conflict and water cooperation with a special focus on the case of Israel and Palestine. It insists that characteristics and dynamics of the earth system (Rettberg, 2010), security threats (Feitelson et al., 2012) and group identities (Ide, 2015) are important in shaping socio-environmental conflict or cooperation, but should be conceived as social constructs rather than as objective facts. More specifically, we portray the dominant water discourses 
in Israel and Palestine (based on a literature review) and compare them to the discourse of an Israeli-Palestinian water cooperation project, the Good Water Neighbours (GWN) project.

In doing so, we contribute to the existing literature in a threefold way. Firstly, we aim to explain the puzzle of the simultaneity of water conflict and cooperation in Israel and Palestine. This refers not only to the simultaneity of water conflict on the inter-state level and water cooperation between the GWN communities, but also refers to the apparent consensus about the perpetuation of the water conflict in Israel and Palestine and the widespread lack of cross-border water cooperation (Daoudi, 2009; Messerschmid, 2012), while GWN communities simultaneously work actively towards replacing the water conflict by water cooperation. Secondly, we contribute to a small, but growing constructivist body of literature in the study of socioenvironmental conflicts (e.g., Fröhlich, 2012; Martin, 2005; Stetter et al., 2011; Zeitoun et al., 2013). In particular, there are very few studies focusing on the discursive and/or narrative dimensions of socio-environmental cooperation (Norman, 2012), especially in the context of wider political conflicts. Thirdly, we empirically test the claims of the constructivist approach. If inter-subjective factors are important in facilitating socio-environmental conflict or cooperation, then the dominant water discourses in Israel and Palestine should be significantly more confrontational and less cooperationprone than the GWN discourse.

The article proceeds as follows: in the next section, the theoretical framework and methodology of this study are described (Sect. 2). Afterwards, we contextualize and portray the dominant water discourses in Israel and Palestine (Sect. 3) before we present the GWN discourse in greater detail (Sect. 4) and draw our conclusion (Sect. 5). Our main result is that discourses are important drivers (although not determinants) of water conflict and water cooperation. This finding needs to be more thoroughly integrated into scientific analyses of socio-environmental conflicts as well as into practices of conflict prevention, conflict transformation and peace-building.

\section{Theory and method of discourse analysis}

\subsection{A discursive understanding of socio-environmental conflict and cooperation}

In this article, we draw on the Sociology of Knowledge Approach to Discourse (SKAD) as developed by Reiner Keller (2011b). This framework is chosen since it combines the strengths of the Foucaultian discourse analytic approach with the insights of the sociology of knowledge in the tradition of Berger/Luckmann (Keller, 2011b). In addition, Keller (2013) provides explicit definitions for his key concepts as well as a comprehensive set of methodological tools and criteria, something which is not the case for all dis- course approaches in peace and conflict studies (e.g., Milliken, 1999).

Keller (2011a, p. 48) defines "discourses as performative statement practices which constitute reality orders and also produce power effects in a conflict-ridden network of social actors." Discourses structure what is accepted as true by a given social group and what is claimed wrong or not considered at all. This also applies to the "subject positions" of social actors, which define the role and characteristics (that is, the identity) of individuals and social groups (Keller, 2011a, p. 49). As Jäger (2004, p. 158) puts it, "a discourse is the flow of social knowledge through time". This drives the conclusion that "everything we perceive, experience, sense is mediated through socially constructed and typified knowledge" (Keller, 2013, p. 61) - in other words, through discourse.

Discourses thus execute significant power effects, since they structure (but not determine) social actors' perceptions and interpretations of reality as well as the actions (or practices) emerging from these interpretations. Discourses become manifested in various concrete speech acts, texts, images and symbols, but also in non-verbal practices. These, in turn, reproduce the very discourse they are originating from. Discourses and practices are therefore mutually constitutive, implying that discourses are simultaneously dynamic (they are reproduced by and can be changed by human action) and static (they structure human action). A discourse is termed dominant if its core statements are accepted as true by a large majority of the members of a certain social group (Keller, 2011a).

This understanding of discourse and the discursive construction of reality can be connected to constructivist conflict theory. Diez et al. (2006, p. 565), for instance, write:

we observe the existence of a conflict when an actor constructs his or her $[\ldots]$ interests in such a way that these cannot be made compatible with the $[\ldots]$ interest of another actor. Conflict is therefore discursively constructed.

In line with this definition, we understand every conflict as driven by mutually incompatible interests. But interests are neither primordial nor strictly rational; instead, they emerge from the perceptions and interpretations of the respective groups (Hansen, 2006; Jabri, 1996), which are constructed by dominant discourses. Two aspects are of particular relevance in this regard: collective identities, or subject positions in the terminology of Keller, and situation assessments. Identities encompass "the formal and informal rules that define group membership [...], the goals that are shared by the members of a group" and relational comparisons with other identity groups (Abdelal et al., 2006, p. 696). In short, collective identities define how the respective groups understand themselves in relation to others and how they define their interests (Buckley-Zistel, 2006; Morozov and Rumelili, 2012). Thus, collective identities are integral to the onset and reproduction of conflict (Fröhlich, 2010, 38-40; Jabri, 1996, p. 5). 
Situation assessments refer to the causality assumptions and perceptions of surrounding material conditions of a (collective) actor. They have shown to be highly relevant for conflict dynamics (Han and Mylonas, 2014; Janis, 1982), especially in socio-environmental conflicts where the perceived extent, causes and solutions for environmental problems are usually disputed between the parties (Wittayapak, 2008; Zeitoun et al., 2013). Numerous studies have shown that divergent environmental perceptions of various groups cannot be resolved by supposedly objective scientific data (e.g., Otto and Leibenath, 2013; Rettberg, 2010). The concept of securitization has proven especially helpful with regard to situation assessments. A securitization exists if a valued reference object (e.g., national sovereignty) is portrayed as existentially threatened, leading to the acceptance of measures which are usually considered as inappropriate or exaggerated, such as the use of violence (Buzan et al., 1998, 21-47; Stritzel, 2007).

Cooperation exists "when one or more parties engage in jointly coordinated actions with other actors to secure shared" interests (Ravnborg et al., 2012, p. 349). As outlined above, interests are shaped by identities and situation assessments. Hence, we consider cooperation as a social continuity, since cooperative - like conflictive - behavior is enabled and shaped by dominant discourses, which evolve slowly over time (Jabri, 1996; Kaufman, 2006). The transformation of a conflictive into a cooperative relationship is possible whenever the interests of the parties involved are constructed as mutually compatible by the dominant discourses of the respective groups. This is the case when the inclusion/exclusion boundary between in-group and outgroup identities is blurred, thereby deconstructing and delegitimizing myths of unity, duty and conformity (Jabri, 1996, p. 7). Cooperation is also facilitated when groups agree in their assessment of a certain situation as a common challenge that provides potential for mutual gains, thus portraying joint problem solving as a rational course of action (Cox et al., 2010; Lejano, 2006).

\subsection{Methodology}

The dominant water discourses in Israel and Palestine were described by drawing on the extensive literature on that issue (see Sect. 3). Although it has faced criticism as well (Aggestam and Sundell-Eklund, 2014; Alatout, 2006), the Good Water Neighbours project (GWN) is considered one of the most elaborate and far-reaching water cooperation projects in the Israeli-Palestinian context (Harari and Roseman, 2008; Kramer, 2008). We thus selected it to study the discourses underpinning water cooperation. The GWN project was initiated by Friends of the Earth Middle East (FoEME) in 2001 and included 20 communities from Israel, the West Bank and the Gaza Strip ${ }^{1}$ by 2013 (FoEME, 2013). The goal of the project is the conservation and improvement of local, cross-border water resources and the increasing of mutual trust and understanding between people from both societies (Harari and Roseman, 2008). By the time of writing, cooperation in water resource management has not been achieved by any of the Israeli-Palestinian community pairs due to administrative obstacles and a lack of political support. However, common activities on issues as diverse as water-related education and awareness raising, the development of crossborder conservation areas, the initiation of water infrastructure projects benefiting both sides, and the prevention of construction works in ecologically and hydrologically sensitive areas have been undertaken (FoEME, 2013; Kramer, 2008).

In order to create the corpus for the discourse analysis, we first collected reports, documents and press releases available on the GWN website. In addition, we conducted 38 semi-structured interviews with 44 activists involved into the GWN project, either as professional staff, as volunteers, or as supporters from the local bureaucracy. ${ }^{2}$ An almost equal number of Israeli (25) and West Bank Palestinian (19) activists from five different community-pairs and the national GWN offices in Bethlehem and Tel Aviv were interviewed. Interviewees were identified according to the snowball sampling technique, which is considered most equivalent in conflict regions characterized by mistrust and potential insecurity (Cohen and Arieli, 2011). In order to single out the influence of discourses, we used the diverse case technique (Gerring, 2007, 89-99) when selecting the five community-pairs. We conducted interviews in communities with great differences in location, size, population structure, history, political affiliation and economic structure. If the same or similar discourses can be detected in cooperating communities which differ considerably with regard to geographical and socio-economic factors, it is likely that cooperation-prone discourses rather than other factors can explain the existence of cooperative relationships (Gerring, 2007, 97-99). Figure 1 provides an overview of the locations and numbers of the interviews conducted. Communities represented by the same symbol are cooperating with each other (the national offices are marked by a circle).

In order to maximize compatibility with our theoretical approach, which draws strongly on SKAD, we largely followed the methodological suggestions made by Keller (2013) when

\footnotetext{
${ }^{1}$ Several communities from Jordan also participate in the project but the focus of this paper is on Israel and Palestine.

${ }^{2}$ All interviews were either conducted in English or in Arabic/Hebrew with the help of a translator. The translators were instructed to translate the interviews as close to the original wording as possible and to pay special attention to formulations with might have an ambiguous or metaphorical meaning. The likelihood of misinterpretations due to not conducting the interviews in the native language of the interviewees was reduced by the comparison of various interviews during the macro-analysis and by a member check of the results (see below).
} 


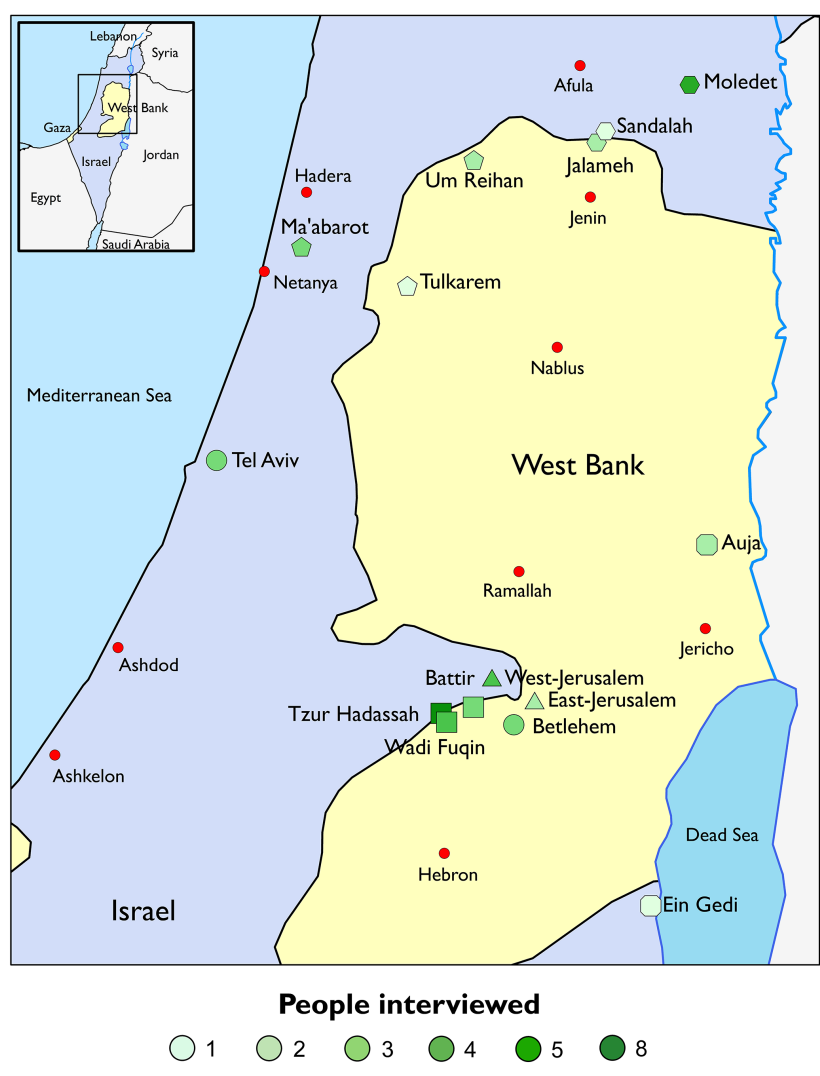

Figure 1. Locations of the interviews with GWN activists.

analyzing the corpus. As advised by Keller (2011b: 251275) and other qualitative researchers (e.g., Böhm, 2012), we combined his approach with elements of the Grounded Theory procedure (Corbin and Strauss, 2008) for the concrete empirical analysis.

We drew on Keller's (2013, 93 pp.) distinction between phases of macro-analysis, during which the corpus was examined more generally in order to get an overview on the data and formulate hypotheses and phases of micro-analysis (see also Jäger, 2004, 171-196). During the latter, selected text passages were analyzed more intensively in order to verify, falsify or modify the hypothesis developed during the macro-analysis and to create new hypotheses. Since an intense qualitative analysis of the whole corpus would have been too time-consuming, the selection of material for the micro-analyses was guided by the previous macro-analyses and by the principles of maximal and minimal contrasting. Maximal contrasting refers to the selection of text passages which are very different in order to reconstruct a discourse as completely as possible. Minimal contrasting implied the intensive analysis of several similar text passages in order to arrive at a deeper understanding of the rules which structure the production of these utterances (Keller, 2013, 129 pp.). Phases of macro- and micro-analysis alternated because the hypotheses created during the macro-analysis has to be con- firmed (or rejected) by the micro-analysis, while for every result of the micro analysis, it was checked whether it is valid for the whole corpus.

For both the macro- and the micro-analyses, we utilized the procedures of open, axial and selective coding according to Grounded Theory (Böhm, 2012; Glaser and Strauss, 1967, 101-115). In this context, coding refers to the translation of the raw data (text passages) into more abstract concepts which can be used as building blocks for the final analysis of the discourse. Codes (e.g., water interdependence, in-group and out-group) were allocated to short passages of texts and accompanied by memos, i.e., short notices about why the specific code was distributed, which alternative interpretations could be possible, how the respective code could relate to other codes and what blind spots of the analysis might exist. At the beginning of the analysis, we kept the codes and memos flexible in order to remain open for alternative interpretations of the material (open coding). As the research proceeded, we synthesized the codes into more robust and elaborated categories (axial coding) and related them to each other in order to carve out the phenomenal structure of the GWN discourse (selective coding). According to Keller (2011b, 240-252), the phenomenal structure is a set of core dimensions which constitute the defining phenomenon of the discourse under investigation (here: water in Israel and Palestine).

Since we conducted parts of the discourse analysis before and during the field research, we were able to apply the idea of theoretical sampling (Corbin and Strauss, 2008, 143-157), that is, interview questions and document sighting priorities were adjusted to hypotheses and blind spots which emerged during the preceding (and preliminary) analysis. This allowed us to remain flexible in the face of surprising findings, an important issue given that to our knowledge, this is the first systematic analysis of the GWN discourse.

The analysis of the GWN discourse was considered saturated when several codes (or dimensions) relevant for the research question were (a) identified, (b) developed in terms of their central characteristics, and (c) related to each other (Corbin and Strauss, 2008, 148 pp.). In order to increase the validity of our study, we shared the preliminary results of the discourse analysis with our interview partners, asked them for feedback ("member check") and carefully reviewed our analysis in case of disagreement (Steinke, 2012, p. 320).

\section{The Israeli-Palestinian water conflict and its discursive foundations}

The Israeli-Palestinian water conflict is shaped by political developments as well as by the region's geographical, climatic, hydro(geo)logical and demographic realities (Feitelson, 2013; Zeitoun, 2008). The region's climate is arid to semi-arid, with frequent droughts which are likely to increase in the future (Feitelson et al., 2012). The most important 
freshwater sources for Israel and the Palestinian territories are the Jordan River (including the Sea of Galilee) and various aquifers. Up to today, the Palestinians have no access to the Jordan River whatsoever (Selby, 2005). The biggest subterranean water reservoirs are the coastal and the mountain aquifer with 240 and 679 million $\mathrm{m}^{3}$ per year respectively (Dombrowsky, 1998, p. 94). Both are considered crucial for the water supply of Israel and Palestine, especially during the dry summer months, and are not confined to either party's territory (Zeitoun, 2008, 45-59).

Ever since the systematic Jewish immigration into Palestine began in the late 19th century, and up until the 1980s, water was of high economic and political relevance for the yishuv - the pre-state Jewish community in Palestine - as well as for Israel (Feitelson, 2002; Lipchin, 2007). It was one of the main outcomes of the Six Day War of 1967 that Israel brought $80 \%$ of the regional water resources under its control. Since then, Israel withdraws much larger quantities of water from the Jordan River and the shared aquifers than the Palestinians, while the latter are entirely dependent on Israeli permissions to develop their water infrastructure (Selby, 2005; Zeitoun and Mirumachi, 2008). The Oslo talks of the 1990s established the Israeli-Palestinian Joint Water Committee (JWC), which brought very little progress in this respect and is thus strongly criticized (Selby, 2013). The dominant water discourses in Palestine and Israel have developed in the context of this stark political asymmetry.

In the discourse that is dominant in Palestine (but marginalized at the international level), the existing natural water resources are believed to be sufficient at least for a major improvement of the Palestinian standard of living (which is not to deny the general limits of water availability in the area). The Israeli control over most of the water sources, the very unequal access to water as well as Israel's capacity to veto water infrastructure projects is seen as the major cause of water availability problems in the West Bank (Alatout, 2006; Waintraub, 2009). In the Palestinian perception, the experienced water scarcity is thus entirely politically induced (Daoudi, 2009; Trottier, 1999). Israeli control over large parts of the regional water resources is considered as an existential threat to Palestinian society and hence securitized in the dominant discourse (Fröhlich, 2012).

This rather confrontational situation assessment is connected to similarly conflictive identity constructions in the dominant Palestinian discourse. Water is perceived as important primarily as an attribute of a territory that is considered rightfully Palestinian and thus crucial for a Palestinian state and identity, but has been under Israeli control since 1967. Consequentially, the Israeli out-group is at least implicitly portrayed in negative terms, since it is unwilling to grant the Palestinians the amount of water that they are not only entitled to, but also depend on to keep their standard of living and to enable at least moderate economic growth (Fröhlich, 2010; Twite, 2009). This discourse reflects a dominant mentality of siege which mirrors the Israeli mentality (see below). One manifestation thereof is the myth of the fellah, a Palestinian peasant who works and sustains his land even in the worst of circumstances - and needs water to do that, while access to water is denied by Israel (Fröhlich, 2012). The central characteristic of the fellah is perseverance (Arabic sumud) in the face of recurring humiliation and assault; the myth is alive until today and relates not only to those who actually work with and on the land, but also those who protect the land by simply maintaining their livelihoods in the Occupied Territories and by witnessing the Israeli occupation.

There certainly are alternative positions which challenge the dominant Palestinian water discourse (Alatout, 2006). Examples include more pragmatic voices that criticize Palestinian water management and thus acknowledge the ingroup's responsibility for the water scarcity and pollution Palestine is experiencing (Fröhlich, 2010). But the dominant discursive pattern is to construct water availability as crucial for the Palestinian identity and future state, to securitize Israeli control over the majority of the natural water resources and to blame the Israeli out-group for being solely responsible for water shortages in the Palestinian territories (Alatout, 2006; Twite, 2009; Waintraub, 2009). The Palestinian dominant water discourse is thus quite confrontational.

Just like its Palestinian counterpart, the Israeli water discourse is far from homogenous (Feitelson, 2002). However, in the dominant Israeli discourse, water is deeply interwoven with agriculture, the creation of a Jewish state/homeland and the Israeli identity. The roots of water's ideological meaning for Israel lie in political Zionism (Lipchin, 2007). The link between Zionism's main goal of a viable Jewish state on biblically promised land and water is agriculture. On the one hand, agriculture made it possible to settle and control the Jewish homeland (Feitelson, 2013). On the other hand, Jewish immigrants could, by working with the land and owning it, shed their European, Western, urban image and substitute it through a new identity: that of the chalutz, the pioneer, who helps to build a Jewish state and thus contributes to the redemption of the "chosen people" (Fröhlich, 2012). Thus, both settlement and agriculture aided the discursive melting of water with the "Zionist [...] ethos of land, pioneer heroics, and national salvation" (Rouyer, 1996, p. 30). A sufficient water supply hence became a vital part of the Jewish-Israeli identity (Fröhlich, 2012), even if water issues (no longer) dominate public debates and media coverage (de Châtel, 2007; Feitelson, 2013).

In addition, the holocaust and the repeated threats by Arab neighbors contributed to the development of a security discourse which conceives of the Jewish state and people as inherently threatened. The discursive securitization of diverse threats developed into one of the most powerful discursive structures in the Israeli societal discourse (Fröhlich, 2010). Generally speaking, a mentality has emerged which cultivates a perpetual state of siege (Bar-Tal, 1998). The water discourse has been taken over by this securitization trend, especially in the face of intense water-related disputes be- 
tween Israel and Syria in the 1950s and 1960s (Amery, 2002). The securitization of water and its central role for the Israeli identity is complemented by a quite confrontational assessment of the water situation in the dominant Israeli discourse. The natural water resources in the Jordan basin are considered scarce and in desperate need to be developed in order to keep the current standard of living of the region's population (Fröhlich, 2012; Messerschmid, 2012).

Since the 1990s, the discourse partially shifted from water quantity to water quality issues (Fischhendler et al., 2011), while large quantities of additional water became available due to wastewater recycling and desalination (Aviram et al., 2014; Spiritos and Lipchin, 2013). Peace treaties and related water agreements were also reached with Jordan and the PLO (Zeitoun, 2008, 68-72). These developments facilitated a desecuritization of water issues, although this trend was negatively influenced by heavy droughts in the late 2000s and predictions of climate change-induced rainfall reductions in the future (Mason, 2013; Messerschmid, 2012). Attempts to achieve more tangible water equality, for instance by conferring parts of the mountain aquifer onto Palestinian control or allowing Palestinians to unilaterally implement water infrastructure projects in the West Bank, remain unsayable (Feitelson and Rosenthal, 2012; Selby, 2009) and are routinely subjected to what we call a re-securitization. Regardless of the afore-mentioned de-securitization impulses, dominant discourse structures still tie back into the much older, persistent securitizing discourse structures, which can be easily activated (Fröhlich, 2012; Messerschmid, 2012).

\section{The Good Water Neighbours discourse}

The GWN activists interviewed share a common discourse, although some differences between an Israeli and a Palestinian version can be detected. In this section, the GWN discourse is described along five dimensions of the phenomenal structure that emerged as particularly relevant during the analysis: relevance of water, water problems, solutions for water problems, out- and in-group images, and governments and politics. Each of these five dimensions was detected in almost all of the interviews conducted.

\subsection{Relevance of water}

Just like the dominant water discourses in Israel and Palestine, the GWN discourse emphasizes the high importance of water. Within the dominant discourses, water is considered important due to its connections either to Zionism or to a viable Palestinian state and the fellah myth. These references are mutually exclusive, contradictive, and eventually confrontational. This stands in sharp contrast to the GWN discourse. Here, water is first and foremost framed as a means to sustain life in general and human life in particular:
Water is the ingredient that made possible the explosion of life on our planet, both in the sea and on land $[\ldots]$ In the desert and semidesert regions such as the Middle East, the development of water systems was crucial for the development and advancement of human culture. (Watercare, 2004, $4-6)^{3}$

Within the Palestinian GWN discourse, water is in addition described as crucial for sustaining the concrete, often agricultural livelihoods of the people in the region. Within the Israeli GWN discourse, water is also considered an important part of a healthy and livable environment. So despite some differences, all three dimensions of the relevance of water as constructed in the GWN discourse (enabling life, securing livelihoods, raising the quality of life) are clearly non-exclusive, since they refer to (benefits for) all inhabitants of the region regardless of their political affiliation or nationality. In this respect, the GWN discourse is considerably less confrontational than the dominant discourses.

This inclusive understanding of the relevance of water is further strengthened by the diagnosis of strong water interdependence in the GWN discourse. This is especially true with regard to the mountain aquifer. An Israeli GWN activist was quite explicit about this when reporting about the benefits of establishing a sewage treatment system in the West Bethlehem region:

Because currently, this village, like all the, the other villages, they are actually polluting their own water [...] But the Israeli mayors will also want that the sewage issue will be dealt with, because Israel also drinks from that same water. So, I think all of our work, the strength of our work, we are identifying self-interest $[. .$.$] And we are identifying that$ self-interest in a, in a manner that speaks to mutual gain. (interview, 13 May 2013, Battir)

This water interdependence is not just diagnosed for the local level, but portrayed as a general fact, at least in the Middle East. Phrases like "water [... ] has no border" (interview, 26 May 2013, Bethlehem) were articulated in nearly every interview conducted.

The identification of water interdependence, self-interest and mutual gains in combination with the depiction of water resources as naturally scarce and vulnerable (see below) but important for all inhabitants of the region represents a significant de-securitization move. Such argumentative support for water cooperation is largely absent in the dominant discourses of both sides, which portray water interaction largely

\footnotetext{
${ }^{3}$ Water Care is a textbook educating middle school pupils about water in the Middle East. It was not written by GWN, but is very frequently used by the project. Several authors of the Water Care textbook are affiliated with FoEME.
} 
as a zero-sum game ${ }^{4}$, thus denying the possibility of mutual gains.

\subsection{Water problems}

The dominant Palestinian discourse focusses overwhelmingly on problems of water quantity, while in Israel, an essential concern about sufficient water availability is combined with growing attention to water quality issues. In the GWN discourse, issues of water quantity and quality are highlighted as well (although Israeli GWN activists tend to emphasize water quality while Palestinian activists focus more often water on quantity issues). There is an agreement that Israelis are facing no water availability problems at the moment, but are threatened by the pollution of cross-border streams and the mountain aquifer. Palestinians are portrayed by the GWN discourse as struck by the same, but more severe problems of water quality and in addition by an alarmingly low water availability. The inclusion of water quality concerns into the set of relevant issues broadens the range of topics available for cooperation, especially since it might be easier to frame interactions on water quality issues as a positive-sum game.

When it comes to the reasons for the existing water problems, the GWN discourse first refers to a bundle of geographical and demographic factors (e.g., arid climate, growing population), which is largely in line with the dominant discourses in both countries. The region's water resources are also portrayed as "highly vulnerable to pollution" (Tagar and Qumsieh, 2006, p. 3). The lack of coordination between the different parties, which would be necessary in a situation of strong water interdependence, is described as accelerating these problems. But in addition, Israeli and Palestinian GWN activists agree that Israeli policies are responsible for water problems. The insufficient water availability in the West Bank is largely described as a function of the Israeli control over water resources, the unwillingness of the Israeli government to share the water equally and Israeli restrictions on water projects in the West Bank. In the words of an Israeli GWN activist:

Then, unfortunately, we had 1967 another war. And this time, Israel occupied, or take, took over the West Bank, and occupied. And since then, Israeli had no, no intention of letting the Palestinian really survive in a proper, decent way [...] To get the pump to a village, to pump water, it will be a procedure of paper work of half a year, or a year,

\footnotetext{
${ }^{4}$ One might argue that recent developments in wastewater recycling and desalination facilitated a shift in the Israeli discourse towards conceiving water no longer as a zero-sum game. While such a shift is visible with regard to Israeli-Jordanian water interactions (Aviram et al., 2014), it has so far not been observed in the IsraeliPalestinian water relationship (Feitelson and Rosenthal, 2012).
}

and now the couple of years before they let you do it. (interview, 14 May 2013, Hadera)

The Israeli government is also held responsible for the water quality problems originating in the West Bank. As a Palestinian GWN activist states:

In the West Bank, yes, we have a, problems with, especially with the springs inside the villages. There is deterioration, there is the pollution, mainly because of the lack of sewage systems [...] All these sanitation projects require Israeli approval. And in many cases, we have donors willing to put money, we have the budgets, but we lack the Israeli permit to proceed ahead with these projects. (interview, 13 May 2013, Battir)

However, an important difference between the Israeli and Palestinian GWN discourses exists. Palestinian GWN activists describe the natural scarcity of water and especially Israeli policies as the main sources of water problems in the West Bank. Consequentially, and in line with the dominant Palestinian discourse, the responsibility of any Palestinian group or institution for the scarcity or pollution of water in the West Bank is denied. Within the Israeli GWN discourse, by contrast, Israel is described as being better off in terms of water not only because it utilizes water resources from the West Bank, but also because of its high administrative, organizational and technological capabilities:

And the, the good thing about it, Israel, is: We always knew how to use the money. They [the first Jews migrating to Israel] were pioneers in the sense that they would not accumulate in their own pocket [...] And as a result, we managed to get our water, among other things, our water system probably one of the most developed in the world. (interview, 14 May 2013, Hadera)

It can be assumed that the shared understanding of Israeli government policies as a key determinant of water problems in the region, and especially in the West Bank, facilitates cooperation within the GWN project. However, disagreement regarding the importance of technological and administrative causes of water problems has the potential to hamper cooperation between GWN activists.

\subsection{Solutions for water problems}

When it comes to the question as to how the water problems in the region can be solved, the GWN discourse favors a solution based on two principles. Firstly, Palestinian water rights have to be acknowledged and regional water resources should be shared in a more equal way. Secondly, following the ideas of strong water interdependence, water as the object of a positive-sum game and lack of coordination as a possible source of water problems, a transnational integration of water resource management is promoted. This management is 
envisaged to be carried out by a bi- or trilateral ${ }^{5}$ water commission in which all parties would have the same rights and duties. As a contrast to the current Israeli-Palestinian JWC, the commission would be responsible for all water resources of the region, or at least for all transboundary water resources in the region:

What I look for is looking at water resources and manage water resources as a unit [...] And then to manage them in this manner. That will be sustainable for anybody who is living on that resources. [...] On the other side, we have to make the governmental bodies that equal effects going to be shared and equal bodies. There is no veto right for somebody. (Interview, 9 May 2013, Bethlehem)

This desire to share water resources more fairly and to manage them as integrated as possible represents another desecuritization move and provides a positive vision supportive of cooperative behavior. It also marks a clear contrast to the dominant water discourses on both sides which clash over the recognition of Palestinian water rights and are more concerned with the allocation (and, in Israel: quality) rather than with the common management of water resources.

\subsection{Identities and out-group images}

Within the Israeli GWN discourse, Palestinians are mostly described in positive and empathic terms. They are usually not referred to primarily as Palestinians, but as neighbors and fellow humans. Sometimes, the boundaries between both identities are even blurred symbolically, for instance when Israelis and Palestinians are said to be "all son of the earth" (interview, 2 May 2013, Tzur Hadassah). Following this logic, many of the Israeli government's measures which complicate the lives of Palestinians from the West Bank, such as the system of checkpoints, the construction of the separation barrier or the lack of permits to work in Israel, are criticized.

But Palestine is also portrayed as a place of corruption, clientelism and lack of work ethos in the Israeli GWN discourses. An example is provided by the following quote:

So, the Palestinians have a very difficult, have a very big difficulty to operate construction plant for sewage, sewage construction plant. They do not have the, the culture for this, the habit for this, they do not have the how to, to collect taxes to maintain the, the projects. And they do not have the, the motivation to do it. (interview, 5 June 2013, Israel ${ }^{6}$ )

Palestine is also sometimes portrayed as an insecure place. This insecurity is attributed to political extremists who resist

\footnotetext{
${ }^{5}$ Most GWN activists advocate an integrated management of the water resources of Israel, Palestine and Jordan.

${ }^{6} \mathrm{No}$ further information on the location of the interview are given here in order to protect the anonymity of the interviewee.
}

any kind of Israeli-Palestinian cooperation. Another aspect of the Israeli GWN discourse is the description of Palestine as an underdeveloped country:

Yah, and they are less developed economically. So, you know the, all the dealing with environmental issues is parallel to economic situation. As much as your situation is good, you, you are free to deal with the environmental things. (interview, 6 May 2013, Gilboa)

The meaning of this development frame is ambiguous. On the one hand, it constitutes another distinction ("developedunderdeveloped") which constructs Israelis as superior to Palestinians. On the other hand, it implies that the water management problems observed cannot be read as an indicator for a supposedly negative Palestinian character trait. Rather, these problems are depicted as typical for poor countries which either lack capabilities or opportunities to improve their water situation.

The Palestinian GWN discourse is characterized by a clear-cut division of the Israeli out-group. The Israeli people are positively described as neighbors who deserve to "live in freedom, security, peace and respect" (interview, 23 May 2013, Wadi Fuqin). Especially for the period prior to the onset of the second Intifada in 2000, relations between Israelis and Palestinians are described as tight and mutually beneficial. However, the Israeli government and settlers are portrayed as ruthless and fanatic:

There are good people in Tzur Hadassah [Israeli city] and the people of Wadi Fuqin [Palestinian village] want to be connected. They do not want to be separated [...] The people I know, I am happy and I want to work with them 100 years more [...] Netanjahu and his government are very, very difficult and they do not want peace. (interview, 22 May 2013, Wadi Fuqin)

The fact that Israel is a democracy and that the government (and its settlement policies) are elected by the majority of the Israeli people is not reflected in the Palestinian GWN discourse.

It can be concluded that the Israeli and Palestinian GWN discourses contain a predominately (but not completely) positive image of the out-group, especially compared to the respective dominant discourses in both countries (e.g., Bar-Tal, 1998; Kaufman, 2009). This largely empathic construction of the other as a neighbor, fellow human and partner is supporting the de-securitization of water issues and facilitates water cooperation.

\subsection{Governments and politics}

As already indicated, the Israeli government is frequently criticized within the GWN discourse. Concrete allegations 
include the occupation of the West Bank, the settlement policies and the construction of the separation barrier, but also the unequal distribution of water and the ignorance of water pollution problems. The construction of such a common negative facilitates the development of a shared identity within the GWN project. The Palestinian Authority, in contrast, is either described as supportive and helpful (Palestinian GWN discourse) or as lacking capabilities (Israeli GWN discourse). The absence of Palestinian critique of the Palestinian Authority represents a contrast to the Israeli GWN discourse, which also blames the Palestinian side as responsible for the water problems occurring within their territory. This is in line with the disagreement about the causes for water problems in the West Bank between Israeli and Palestinian GWN activists and the partially negative out-group images in the Israeli GWN discourse, thus representing a potential obstacle to cooperation.

Politics in general is described as a predominantly negative realm (also in Palestine, where the evaluation of the government is quite positive). According to the GWN discourse, political activities are often inspired by a top-down approach, which is less effective and ignores local realities. Related to that, politicians are described as not knowing or not even caring about the lives and thoughts of "normal" people. Rather, they are pursuing goals motivated by ideology or the interests of some particular groups. In the words of a Palestinian GWN activist:

The politicians do not know really what is going on ground. Really, they do not know [...] Whether they are the small-rank or the high-rank, have lost the feelings. When they become politicians, they lose the feeling of simple or normal humanitarian, or human, humanity. (interview, 21 May 2013, Um Reihan)

It is likely that the appreciation of bottom-up approaches as well as skepticism about the established political actors' willingness and capacity to solve water problems provides a motivation for the GWN activists to engage in bottom-up cooperative problem solving.

\section{Conclusions}

Based on an analysis of the existing literature, we conclude that confrontational, contradictive and mutually exclusive identities and situation assessments are major drivers of the Israeli-Palestinian water conflict. This applies to the interstate level, but it also explains why many communities along the border between Israel and the West Bank abstain from cooperation over local water resources. Such cooperation is taking place in the GWN project. The GWN discourse is characterized by largely (although not completely) inclusive identities and de-securitized situation assessments which highlight the need for water cooperation and more equitable water sharing. Given the (political, historical, economic and ecological) heterogeneity of the communities analyzed, these findings provide support for the theoretical premises of the constructivist literature on socio-environmental conflict and cooperation discussed in Sects. 1 and 2.1. ${ }^{7}$

Therefore, we conclude that discourses are important facilitators of socio-environmental conflict and cooperation on the international, national and local levels. Although this claim needs further empirical testing in different contexts, there are indicators that our conclusion is valid for other cases as well. With regard to local pastoralist conflicts in East Africa, for instance, several authors highlight the relevance of (discursively constructed) precipitation perceptions and exclusive identities (Ide et al., 2014; Temesgen, 2010). In the same context, discourses emphasizing mutual gains and past collaboration facilitate cooperative adaptation to droughts (Bogale and Korf, 2007). Similarly, a partial shift from discourses of zero-sum competition and water securitization to discourses about water interdependence and benefit-sharing has proven crucial for the emergence of more cooperative interactions on the Euphrates and Tigris between Turkey, Iraq and Syria in the 2000s (Kibaroglu and Scheumann, 2013; Sümer, 2014). In the words of Lene Hansen (2006, p. 214), "'facts', 'events', and 'material factors' did not in and of themselves produce policy."

If discursively constructed identities and situation assessments are important explanatory factors for the occurrence of conflict and/or cooperation over water resources, attempts to find accepted and sustainable solutions to water conflicts should focus on those discourses, too (Buckley-Zistel, 2006). Concentrating exclusively on technical or functional water cooperation is insufficient at best and counterproductive at worst (Aggestam and Sundell-Eklund, 2014; Bichsel, 2009).

Israeli investments in wastewater recycling and seawater desalination have considerable increased the amount of water available in Israel and Palestine considerably. But this has caused no transformation of either the confrontational dominant water discourses or the inter-state water conflict so far (Aviram et al., 2014). Therefore, investing development aid or peace-building funds solely in water infrastructure projects seems unwise, especially in the West Bank, where permission for such projects is hard to achieve (Selby, 2013). Based on our research results, it seems more promising to support local initiatives which embed water infrastructure developments in broader reconciliation efforts or which engage in discursive conflict transformation (Ochs et al., 1996).

\footnotetext{
${ }^{7}$ One might argue that the respective discourses are not a facilitating factor for, but rather an outcome of cooperative behavior between the GWN communities. We regard this as unlikely because discourses structure how people essentially conceive the world (and consequentially act towards it). Moreover, they are historical phenomena that only change slowly over time. In line with this, groups are very unlikely to cooperate with world views and motivations as confrontational as the ones we have identified in the Israeli and Palestinians dominant discourses.
} 
This resonates well with current debates which are critical of the liberal peace-building approach and its focus on external, "one size fits all" technological fixes. Scholars increasingly recommend strengthening the local (and the associated values and initiatives) in peace-building efforts (Richmond, 2009). Of course, the question about the "true" nature of the local remains (Mac Ginty and Richmond, 2013), for instance when Palestinian GWN activists report instances of (local) resistance against the project. Asked whether (s)he had encountered any skepticism about the GWN project from local people, an activist from the Palestinian village of Auja responded:

This is what we managed to overcome. Ok? Because when we started here working in Auja, they said that is, that institution is normalization. ${ }^{8}$ (interview, 7 June 2013, Auja)

In a nutshell, a discursive approach to socio-environmental conflict and cooperation not only yields important analytical insights; transforming confrontational attitudes and perspectives into (locally grounded) cooperative identities and situation assessments is also a promising way for promoting environmental conflict resolution and environmental peacebuilding.

Acknowledgements. Research for this study was funded in part by the German Environmental Foundation (DBU) and the German Science Foundation's (DFG) Cluster of Excellence Integrated Climate System Analysis and Prediction (CliSAP) (EXC177). Pina von Prozinski provided great help in designing Fig. 1. We are grateful to our interview partners who shared their time and insights with us as well as to the reviewers who provided valuable feedback. All remaining errors are our own.

Edited by: J. Link

\section{References}

Abdelal, R., Herrera, Y., Johnston, A. I., and McDermott, R.: Identity as a variable, Perspect. Politics, 4, 695-711, 2006.

Aggestam, K. and Strömbom, L.: Disempowerment and marginalisation of peace NGOs: exposing peace gaps in Israel and Palestine, Peacebuilding, 1, 109-124, 2013.

Aggestam, K. and Sundell-Eklund, A.: Situating water in peacebuilding: revisiting the Middle East peace process, Water Int., 39, 10-22, 2014.

Alatout, S.: Towards a bio-territorial conception of power: territory, population, and environmental narratives in Palestine and Israel, Polit. Geogr., 25, 601-621, 2006.

\footnotetext{
${ }^{8}$ Normalization is a negative term used in Palestine. It refers to the establishment of routine political, economic and cultural relationships with Israel. These are considered inadequate in the context of the ongoing Israeli occupation of the West Bank and isolation of the Gaza Strip.
}

Amery, H.: Water wars in the Middle East: a looming threat, Geograph. J., 168, 313-323, 2002.

Aviram, R., Katz, D., and Shmueli, D.: Desalination as a gamechanger in transboundary hydro-politics, Water Policy, 16, 609624, 2014.

Barnett, J. and Adger, W. N.: Climate change, human security and violent conflict, Political Geogr., 26, 639-655, 2007.

Bar-Tal, D.: Societal beliefs in times of intractable conflict: the Israeli case, Int. J. Conflict Manage., 9, 22-50, 1998.

Bichsel, C.: It's about more water: natural resource conflicts in Central Asia, in: Environmental peacebuilding: managing natural resource conflicts in a changing world, edited by: Péclard, D., Swisspeace, Bern, 32-40, 2009.

Bogale, A. and Korf, B.: To share or not to share? (Non-)Violence, scarcity and resource access in Somali Region, Ethiopia, J. Develop. Stud., 43, 743-765, 2007.

Böhm, A.: Theoretisches Codieren: Textanalyse in der Grounded Theory, in: Qualitative Forschung: ein Handbuch, edited by: Flick, U., von Kardorff, E., and Steinke, I., Rowohlt, Reinbek, 475-485, 2012.

Buckley-Zistel, S.: In-between war and peace: identities, boundaries, and change after violent conflict, Millenium, 35, 3-21, 2006.

Buzan, B., Wæver, O., and de Wilde, J.: Security: a new framework for analysis, Lynne Rienner, Boulder, 1998.

Cascão, A. E.: Ethiopia - challenges to Egyptian hegemony in the Nile basin, Water Policy, 10, 13-28, 2008.

Cohen, N. and Arieli, T.: Field research in conflict environments: methodological challenges and snowball sampling, J. Peace Res., 48, 423-435, 2011.

Conca, K. and Dabelko, G.: The problems and possibilities of environmental peacemaking, in: Environmental peacemaking, edited by: Conca, K. and Dabelko, G., John Hopkins University Press, Baltimoore, 220-233, 2002.

Corbin, J. and Strauss, A. L.: Basics of qualitative research: techniques and procedures for developing grounded theory, 3rd Edn., Sage, London, 2008.

Coskun, B. B.: Cooperation on water resources as a tool for desecuritzation, Eur. J. Econ. Polit. Stud., 2, 97-115, 2009.

Cox, M., Arnold, G., and Tomás, S. V.: A review of design principles for community-based natural resource management, Ecol. Soc., 15, 38-56, 2010.

Daoudi, M. D.: Conceptualization and debate on environmental and human security in Palestine, in: Facing global environmental change: environment, human, energy, food, health and water security concepts, edited by: Brauch, H. G., Oswald Spring, Ú., Grin, J., Mesjasz, C., Kameri-Mbote, P., Chadha Behera, N., Courou, B., and Krummenacher, H., Springer, Berlin, Heidelberg, 873-883, 2009.

de Châtel, F.: Perceptions of water in the Middle East, in: Water resources in the Middle East: Israeli-Palestinian water issues from conflict to cooperation, edited by: Shuval, H. and Dweik, H., Springer, Berlin, Heidelberg, 53-60, 2007.

Deligiannis, T.: The evolution of environment-conflict research: toward a livelihood framework, Global Environ. Polit., 12, 78-100, 2012.

Derman, B., Odgaard, R., and Sjaastad, E. (Eds.): Conflicts over land and water in Africa, James Currey, Oxford, 2008. 
Diez, T., Stetter, S., and Albert, M.: The European Union and border conflicts: the transformative power of integration, Int. Organ., 60, 563-593, 2006.

Dombrowsky, I.: The Jordan river basin: prospects for cooperation within the Middle East peace process?, in: Water in the Middle East: potentials for conflicts and prospects for cooperation, edited by: Scheumann, W. and Schiffler, M., Springer, Berlin, 91-112, 1998.

Duffy, R.: The potential and pitfalls of global environmental governance: the politics of transfrontier conservation areas in Southern Africa, Political Geogr., 25, 89-112, 2006.

Feitelson, E.: Implications of shifts in the Israeli water discourse for Israeli-Palestinian water negotiations, Political Geogr., 21, 293318, 2002.

Feitelson, E.: The four eras of Israeli water policies, in: Water policy in Israel: context, issues and options, edited by: Becker, N., Springer, Berlin, 15-32, 2013.

Feitelson, E. and Rosenthal, G.: Desalination, space and power: the ramifications of Israel's changing water geography, Geoforum, 43, 272-284, 2012.

Feitelson, E., Tamimi, A., and Rosenthal, G.: Climate change and security in the Israeli-Palestinian context, J. Peace Res., 49, 241257, 2012.

Fischhendler, I., Dinar, S., and Katz, D.: The politics of unilateral environmentalism: conflict over water-management along the Israeli-Palestinian border, Global Environ. Polit., 11, 36-61, 2011.

FoEME: Community based problem solving on water issues: crossborder "priority initiatives" of the Good Water Neighbours project, FoEME, Amman, Bethlehem, Tel Aviv, 2013.

Fritz, C. E.: Disasters and mental health: therapeutic principles drawn from disaster studies, Disaster Research Center, Newark, 1996.

Fröhlich, C.: Der israelisch-palästinensische Wasserkonflikt: diskursanalytische Betrachtungen, VS-Verlag, Wiesbaden, 2010.

Fröhlich, C.: Security and discourse: the Israeli-Palestinian water conflict, Conflict, Secur. Develop., 12, 123-148, 2012.

Funder, M., Bustamante, R., Cossio, V., Huong, P. T. M., van Koppen, B., Mweemba, C., Nyambe, I., Phuong, L. T. T., and Skielboe, T.: Strategies of the poorest in local water conflict and cooperation: evidence from Vietnam, Bolivia and Zambia, Water Alternat., 5, 20-36, 2012.

Gerring, J.: Case study research: principles and practices, Cambridge University Press, New York, 2007.

Glaser, B. G. and Strauss, A. L.: The discovery of grounded theory: strategies for qualitative research, Aldine de Gruyter, New York, 1967.

Han, E. and Mylonas, H.: Interstate relations, perceptions, and power balance: explaining China's policies toward ethnic groups, 1949-1965, Secur. Stud., 23, 148-181, 2014.

Hansen, L.: Security as a practice: discourse analysis and the Bosnian war, Routledge, London, 2006.

Harari, N. and Roseman, J.: Environmental peacebuilding, theory and practice: a case study of the Good Water Neighbours project and in depth analysis of the Wadi Fukin/Tzur Hadassah communities, FoEME, Amman, Bethlehem, Tel Aviv, 2008.

Homer-Dixon, T.: Environmental scarcity and violence, Princeton University Press, Princeton, 1999.
Ide, T.: Why do conflicts over scarce renewable resources turn violent? A qualitative comparative analysis, Global Environ. Change, 33, 61-70, 2015.

Ide, T. and Scheffran, J.: On climate, conflict and cumulation: suggestions for integrative cumulation of knowledge in the research on climate change and violent conflict, Global Change Peace Secur., 26, 263-279, 2014.

Ide, T., Schilling, J., Link, J. S. A., Scheffran, J., Ngaruiya, G., and Weinzierl, T.: On exposure, vulnerability and violence: spatial distribution of risk factors for climate change and violent conflict across Kenya and Uganda, Political Geogr., 43, 68-81, 2014.

IPCC: Climate change 2014: impacts, adaptation, and vulnerability, IPCC, Geneva, 2014.

Isaac, J. and Shuval, H. (Eds.): Water and peace in the Middle East, Elsevier, Amsterdam, 1994.

Jabri, V.: Discourses on violence: conflict analysis reconsidered, Manchester University Press, Manchester, 1996.

Jäger, S.: Kritische Diskursanalyse: eine Einführung, UnrastVerlag, Münster, 2004.

Janis, I.: Groupthink: psychological studies of policy decisions and fiascoes, 2nd Edn., Houghton Mifflin, Boston, 1982.

Kaufman, S.: Symbolic politics or rational choice? Testing theories of extreme ethnic violence, Int. Secur., 30, 45-86, 2006.

Kaufman, S.: Narratives and symbols in violent mobilization: the Palestinian-Israeli case, Secur. Stud., 18, 400-434, 2009.

Keller, R.: The sociology of knowledge approach to discourse (SKAD), Human Stud., 34, 43-65, 2011 a.

Keller, R.: Wissenssoziologische Diskursanalyse: Grundlegung eines Forschungsprogramms, 3rd Edn., VS-Verlag, Wiesbaden, 2011b.

Keller, R.: Doing discourse research: an introduction for social scientists, Sage, London, 2013.

Kibaroglu, A. and Scheumann, W.: Evolution of transboundary politics in the Euphrates-Tigris river system: new perspectives and political challenges, Global Govern., 19, 279-305, 2013.

Kramer, A.: Regional water cooperation and peacebuilding in the Middle East, Adelphi Research, Berlin, 2008.

Lautze, J., Reeves, M., Vega, R., and Kirshen, P.: Water allocation, climate change, and sustainable Peace: the Israeli proposal, Water Int., 30, 197-209, 2005.

Lejano, R.: Theorizing peace parks: two models of collective action, J. Peace Res., 43, 563-581, 2006.

Lipchin, C.: Water, agriculture and zionsim: exploring the interface between policy and ideology, in: Integrated water resources management and security in the Middle East, edited by: Lipchin, C., Pallant, E., Saranga, D., and Amster, A., Springer, Dordrecht, 251-268, 2007.

Mac Ginty, R. and Richmond, O.P.: The local turn in peace building: a critical agenda for peace, Third World Quart., 34, 763-783, 2013.

Martin, A.: Environmental conflict between refugee and host communities, J. Peace Res., 42, 329-346, 2005.

Mason, M.: Climate change, securitisation and the IsraeliPalestinian conflict, Geograph. J., 179, 298-308, 2013.

Messerschmid, C.: Reality and discourses of climate change in the Israel-Palestinian conflict, in: Climate change, human security and violent conflict: challenges for societal stability, edited by: Scheffran, J., Brzoska, M., Brauch, H. G., Link, P. M., and Schilling, J., Springer, Berlin, Heidelberg, 423-459, 2012. 
Milliken, J.: The study of discourse in international relations: a critique of research and methods, Eur. J. Int. Relat., 5, 225-254, 1999.

Moore, D. and Guy, A.: The Israeli-Palestinian conflict: the sociohistorical context and the identities it creates, in: Handbook of ethnic conflict: international perspectives, edited by: Landis, D. and Albert, R., Springer, New York, 199-240, 2012.

Morozov, V. and Rumelili, B.: The external constitution of European identity: Russia and Turkey as Europe-makers, Cooperation Conflict, 47, 28-48, 2012.

Norman, E. S.: Cultural politics and transboundary resource governance in the Salish Sea, Water Alternat., 5, 138-160, 2012.

Nyong, A.: Climate-related conflicts in West Africa, Environ. Change Secur. Program Rep., 12, 36-42, 2007.

Ochs, E., Smith, R. C., and Taylor, C. E.: Detective stories at dinnertime: problem solving through co-narration, in: Disorderly discourse, edited by: Briggs, C. L., Oxford University Press, Oxford, 95-113, 1996.

Otto, A. and Leibenath, M.: The interrelation between collective identities and place concepts in local wind energy conflicts, Local Environ., 19, 660-676, 2013.

Ravnborg, H. M., Bustamante, R., Cissé, A., Cold-Ravnkilde, S. M., Cossio, V., Djiré, M., Funder, M., Gómez, L. I., Le, P., Mweemba, C., Nyambef, I., Paz, T., Pham, H., Rivas, R., Skielboe, T., and Yen, N. T. B.: Challenges of local water governance: the extent, nature and intensity of local water-related conflict and cooperation, Water Policy, 14, 336-357, 2012.

Rettberg, S.: Contested narratives of pastoral vulnerability and risk in Ethiopia's Afar region, Pastoralism, 1, 248-273, 2010.

Richmond, O. P.: Becoming liberal, unbecoming liberalism: liberallocal hybridity via the everyday as a response the paradoxes of liberal peacebuilding, J. Intervent. Statebuild., 3, 324-344, 2009.

Rouyer, A. R.: Zionism and water: influences on Israel's future water policy during the pre-state period, Arab Stud. Quart., 18, 2547, 1996.

Schilling, J., Opiyo, F., and Scheffran, J.: Raiding pastoral livelihoods: motives and effects of violent conflict in north-eastern Kenya, Pastoralism, 2, 1-16, 2012.

Selby, J.: The geopolitics of water in the Middle East: fantasies and realities, Third World Quart., 26, 329-349, 2005.

Selby, J.: 'New security thinking' in Israeli-Palestinian water relations, in: Facing global environmental change: environment, human, energy, food, health and water security concepts, edited by: Brauch, H. G., Oswald Spring, Ú., Grin, J., Mesjasz, C., KameriMbote, P., Chadha Behera, N., Courou, B., and Krummenacher, H., Springer, Berlin, Heidelberg, 623-631, 2009.
Selby, J.: Cooperation, domination and colonisation: the IsraeliPalestinian joint water committee, Water Alternat., 6, 1-24, 2013.

Spiritos, E. and Lipchin, C.: Desalination in Israel, in: Water policy in Israel: context, issues and options, edited by: Becker, N., Springer, Berlin, 101-123, 2013.

Steinke, I.: Gütekriterien qualitativer Forschung, in: Qualitative Forschung: ein Handbuch, 9th Edn., edited by: Flick, U., von Kardorff, E., and Steinke, I., Rowohlt, Reinbek, 319-331, 2012.

Stetter, S., Herschinger, E., Teichler, T., and Albert, M.: Conflicts about water: securitization in a global context, Conflict Cooperation, 46, 441-459, 2011.

Stritzel, H.: Towards a theory of securitization: Copenhagen and beyond, Eur. J. Int. Relat., 13, 357-383, 2007.

Sümer, V.: A chance for a pax aquarium in the Middle-East? Transcending the six obstacles for transboundary water cooperation, J. Peacebuild. Develop., 9, 83-89, 2014.

Tagar, Z. and Qumsieh, V.: A seeping time bomb: pollution of the mountain aquifer by solid waste, FoEME, Amman, Bethlehem, Tel Aviv, 2006.

Temesgen, A. K.: Climate change to conflict? Lessons from southern Ethiopia and northern Kenya, Fafo, Oslo, 2010.

Trottier, J.: Hydropolitics in the West Bank and Gaza, PASSIA, Jerusalem, 1999.

Twite, R.: Security and environment and the Israel-Palestine conflict, in: Facing global environmental change: environment, human, energy, food, health and water security concepts, edited by: Brauch, H. G., Oswald Spring, Ú., Grin, J., Mesjasz, C., KameriMbote, P., Chadha Behera, N., Courou, B., and Krummenacher, H., Springer, Berlin, Heidelberg, 865-872, 2009.

Waintraub, N.: Water and the Middle East peace process, Potentia, 1, 23-35, 2009.

Watercare: Water, Mulilateral Working Group on Water Resources, Jerusalem, 2004.

Wittayapak, C.: History and geography of identifications related to resource conflicts and ethnic violence in northern Thailand, Asian Pacific Viewpoint, 49, 111-127, 2008.

Zeitoun, M.: Power and water in the Middle East: the hidden politics of the Palestinian-Israeli water conflict, Tauris, London, 2008.

Zeitoun, M. and Mirumachi, N.: Transboundary water interaction I: reconsidering conflict and cooperation, Int. Environ. Agree., 8, 297-316, 2008.

Zeitoun, M., Talhami, M., and Eid-Sabbagh, K.: The influence of narratives on negotiations and resolution of the upper Jordan river conflict, Int. Negotiat., 18, 293-322, 2013. 